

\title{
Application of Islamic Counselling and Adler Individual Counselling Model in Dealing with Mental Health Issues
}

Norfatmazura Che Wil and Nooraini Othman

To Link this Article: http://dx.doi.org/10.6007/IJARBSS/v11-i11/11168

DOI:10.6007/IJARBSS/v11-i11/11168

Received: 12 September 2021, Revised: 17 October 2021, Accepted: 27 October 2021

Published Online: 18 November 2021

In-Text Citation: (Wil \& Othman, 2021)

To Cite this Article: Wil, N. C., \& Othman, N. (2021). Application of Islamic Counselling and Adler Individual Counselling Model in Dealing with Mental Health Issues. International Journal of Academic Research in Business and Social Sciences, 11(11), $1161-1171$.

Copyright: (c) 2021 The Author(s)

Published by Human Resource Management Academic Research Society (www.hrmars.com)

This article is published under the Creative Commons Attribution (CC BY 4.0) license. Anyone may reproduce, distribute, translate and create derivative works of this article (for both commercial and non-commercial purposes), subject to full attribution to the original publication and authors. The full terms of this license may be seen at: http://creativecommons.org/licences/by/4.0/legalcode

Vol. 11, No. 11, 2021, Pg. 1161 - 1171

Full Terms \& Conditions of access and use can be found at http://hrmars.com/index.php/pages/detail/publication-ethics 


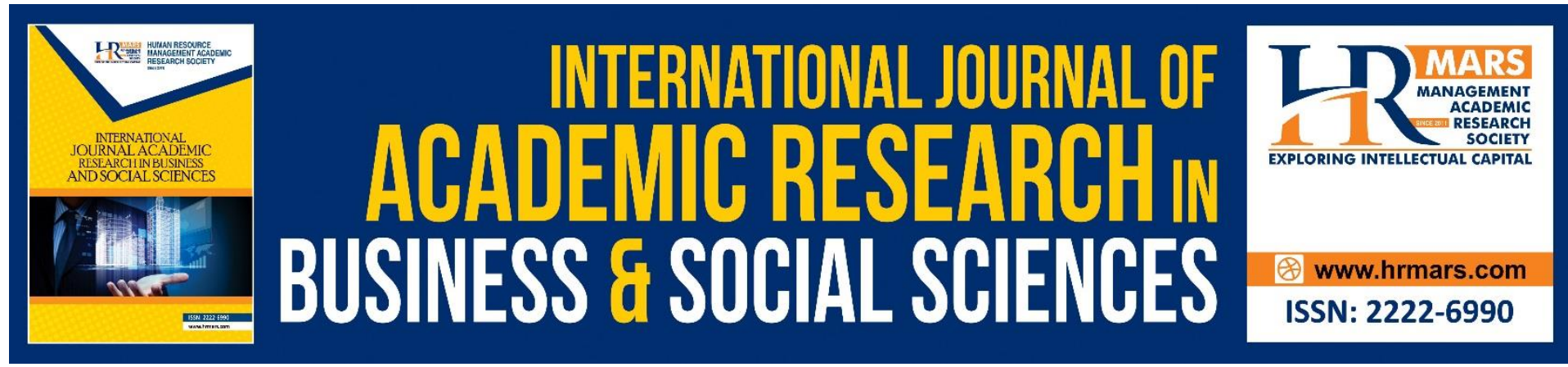

\title{
Application of Islamic Counselling and Adler Individual Counselling Model in Dealing with Mental Health Issues
}

\author{
Norfatmazura Che Wil ${ }^{1}$ and Nooraini Othman ${ }^{2}$ \\ ${ }^{1}$ PhD Researcher, Razak Faculty of Technology and Informatics, Universiti Teknologi \\ Malaysia, Kuala Lumpur, Malaysia and ${ }^{2}$ Professor, Razak Faculty of Technology and \\ Informatics, Universiti Teknologi Malaysia
}

\begin{abstract}
The increase in mental health issues over time has shown that various forms of treatment and interventions are needed to address them. Looking at this importance, this study was conducted aimed at building an application model of Islamic counseling and Adler Individual counseling as an intervention method to address mental health issues. A total of 232 verses of the Quran contained in 61 Surahs, and 36 literature reviews from within and outside the country were analyzed using thematic methods Atlas. ti application. The themes identified through this method of analysis have successfully formed two concepts of Islamic counseling, firstly namely the concept of knowledge and deeds and secondly the concept of faith and confidence, as well as the five concepts of Adler Individual counseling, namely social interests, past experiences, family clusters, feelings of inferiority and lifestyle. These identified concepts are then incorporated and applied into the construction of the intervention model. Apart from this concept, the findings of the study also show the role of counselors in terms of characteristics and skills demonstrated by counselors is also an element that determines the success of counseling sessions as well as helping clients increase resilience as one of the mechanisms to address mental health issues. This study has implications for all levels of society, especially counselors and researchers, as a reference and source of information for further research in the future.
\end{abstract}

Keywords: Islamic Counseling, Individual Counseling, Counselor, Mental Health, Resilience.

\section{Introduction}

Mental health is a very important aspect of every phase of human life. According to the World Health Organization (WHO) (2015), mental health refers to the level of well-being in which individuals are aware of their abilities and capabilities, able to absorb stress in life, productive, and able to contribute to society in other words, it refers to the way they think, feel, act, face problems and overcome them and even be able to interact with others (Ministry of Health Malaysia, 2019). The inability to absorb various challenges causes individuals to have difficulty in maintaining mental well -being thus leading to various disorders such as depression, panic, stress and suicide. According to the National Health and Morbidity Survey (2019), nearly half a million people in the country suffer from symptoms of stress and depression, of which 
424,000 children suffer from mental health issues. Statistics from the National Health and Mobility Survey (NHMS) in 2017 also revealed that an estimated $18.3 \%$ of adolescents aged 13 to 17 years suffered from depression, $39.7 \%$ suffered from anxiety, and $9.67 \%$ faced stress.

Apart from being influenced by several aspects such as the environment, friends and the stigma of the surrounding community on mental health, the spread of the Covid-19 pandemic that has hit the world has caused various control measures to be taken by the government, especially the Movement Control Order (MCO) which gives a huge impact on the lives of individuals. The changes that have taken place in the original norms, conflicts between individuals, ineffective communication, economic factors and so on have caused individuals to face various challenges that ultimately affect their mental health. Thus, failure to cope with change and the process of adjustment has caused individuals to experience a variety of stress, depression and ultimately suicidal acts.

Resilience is the main resource that can help individuals build internal and external strength as the best means of defence. However, there are various obstacles in the process of building resilience, such as self-acceptance, support system and personality. Individuals with mental health disorders are often perceived as "too dramatic" or "weak", and some are considered crazy, weak, overly sensitive, want attention and lack self-confidence causing them to fear and fail to increase the courage to seek help. To ensure that mental health problems can be curbed, various appropriate methods need to be explored and applied to individuals, especially in increasing resilience. Accordingly, the role of counsellors and counselling services themselves is indeed the best medium to help them increase resilience through the best methods, techniques and interventions that can be applied in counselling sessions. Guided by the awareness of the importance of counselling as the best system, this writing focuses on building a model that involves the concept of Islamic counselling and conventional counselling as one form of intervention that can be applied to individuals in need.

\section{Literature Review}

Counselling is a two-way professional relationship between a counsellor and a client in the process of guidance by established ethics. According to the Malaysian Board of Counselors, counselling is defined as a systematic process based on psychological principles that must be implemented by registered counsellors in accordance with the counselling code of ethics set to achieve a holistic change, progress and adjustment. This definition is also supported by the American Association of Counselors (ACA), which states that counselling is a professional relationship to assist the development of individuals, families and groups in achieving the goals of success, mental health, personal well-being, education and career. Khalid (2017) stated that counselling services are an approach that can help individuals to increase resilience in themselves.

According to Ibrahim \& Muhammad (2016), in order to maintain a good level of mental health, a high build of resilience is needed where aspects of self-confidence, self-discipline, self-efficacy, self-control and self-determination are the main aspects of resilience building, especially for teenagers. Although resilience has existed naturally in humans, its methods and implementation are different from each other. Mohamad \& Rathnakrishnan (2014) found that social support factors influence individual loneliness and emotions, whereas those with adequate social support have a lower risk of engaging with negative emotional changes such 
as stress, anger, hate, resentment and depression than other individuals who do not have good support. The study's findings also show that good support is an important aspect of building resilience as a source of internal strength. Good resilience can help individuals gain psychological stability, good self-control, and more controlled emotions, which have a great influence on mental health.

The ability to absorb all the negative elements that are around and the ability to deal with problems is referred to as resilience. Good resilience is a very important mechanism in helping individuals overcome mental health problems. According to Jessie \& James (2017), resilience can be built through exposure to challenging experiences, i.e., feelings of security and high efficiency, but stress is inherent as a result of psychological discomfort that has the potential for depression and other mental health problems. In order to form and increase resilience in an individual, the inner strength that is formed requires the strength that exists through help, support, treatment from oneself, parents, family, peers and society. According to Sanu \& Rathnakrishnan (2019), psychological well-being is an important aspect in determining an individual's happiness and mental health, whereas individuals with good emotional intelligence tend to have more stable mental health. Mamat (2016) states that emotional intelligence is influenced by the acceptance, treatment, feelings and support received from the environment. Good acceptance will cause individuals to have more stable emotions and the ability to monitor themselves in terms of actions and thoughts while affecting the level of mental health. One of the best forms of support is through counselling services which are able to help build emotional intelligence, improve the support system and at the same time increase the building of resilience in individuals through built-in interventions. Nen \& Ibrahim (2018) stated that the counselling approach allows individuals to obtain good sources of support, can be a medium to express problems, emotions and help identify themselves and good problem solving compared to other methods.

However, the reliance on theories from conventional counselling results in the spiritual element not being given emphasis (Awang, 2016) as a source of resilience. Tunggak et al (2015) stated that apart from individual factors, family, peers and environment, religious factors also play an important role in building resilience among individuals ((Muhammad et al. 2017), especially the application of counselling and da'wah psychology (Amila et al., 2017). This matter is also supported by Abd Majib et al (2019), who also stated that religious factors are an important basis for the process of moral change. Religious elements have high importance in the recovery process through the concept of continuous treatment with a combination of spiritual and physical aspects through continuous effort, prayer and trust (Jailani \& Osman, 2015). Yaacob (2012) states that counselling techniques and practices that lead to the elements of guidance based on the attributes of the Prophet SAW (Diniaty, 2013) and Al-Quran and As-Sunnah should be applied in the actual counselling session. In addition, the role of the counsellor brings noble values such as patience, contentment, believing in Qada and Qadar, accepting and believing in wisdom are the values that need to be shown to the client as the core to the formation of resilience (Masroom et al., 2015). Therefore, based on this importance, this article focuses on a model building by taking individual and spiritual needs into account through counselling skills to help increase resilience among individuals. 


\section{Methodology}

This study involves an analytical method in which the research methodology is done based on data from primary and secondary data that consists of the Quran, Hadith, As-Sunnah and writing journals and books related to Individual counselling, Islamic counselling and resilience. A total of 232 verses of the Quran from 61 Surahs and 36 literature reviews from within and outside the country were analyzed using thematic analysis by Atlas. ti applications. The themes identified through analysis are then developed the best concepts of both approaches and ultimately applied in the construction of intervention models.

\section{Findings and Discussions}

\section{Islamic Counselling and Adler Individual Counselling Model}

To ensure there is a balance between the spiritual and the individual, this article will emphasize the selection of concepts from Islamic counselling and Adler's Individual counselling. This selection is made based on analysis and references from the Quran, AsSunnah and Hadith, which this concept is seen to have high priority and effectiveness to be applied to increase individual resilience. The concepts of knowledge and deeds as well as beliefs and convictions that are emphasized in Islamic counselling, for example, are important elements as a spiritual resource. In addition, the importance of exploring individual development in terms of interests, communication and personality is also an important aspect of resilience-building, as emphasized in Adler's Individual counselling. To ensure that counselling sessions can be implemented better and achieve the set goals, the role of the counsellor is also a very important aspect, especially as a role model. The skills and characteristics demonstrated by the counsellor have a great influence on the client's change and the success of the sessions conducted. Thus, the concept of Islamic counselling, Adler's Individual counselling and the role of the counsellor are key elements to the formation of this model.

\section{a. Islamic Counseling Concepts}

The main element emphasized in this model is Islamic counselling. Islamic counselling is a process of a counsellor helping an individual to achieve a goal in which decisions and selections are made based on the Quran, As-Sunnah and Hadith. Spiritual strength refers to the individual beliefs which are built in the context of Islam. Spirituality refers to the individual's belief in Allah SWT and His power (Badri, 2000). The difficulties and challenges that have to be faced in the world cause most individuals to be careless and forget about faith in Allah SWT and seek the pleasure of Allah SWT, so much so that some question the actions and destinies faced by them as stated in the hadith which means:

"Strive for what is favourable to you, and seek God's help, and do not be weak. If you had come upon a certain (failure), do not say, 'Had I done so, it would not have been, or so, ' but say, 'Allah and Allah decreed this to do according to what he wills.' Indeed, the word if it would open the act of Satan."

(Hadith of Muslim History)

As such, Islamic counselling plays an important role in providing awareness and helping individuals to build resilience and self-resilience through spiritual strength. Believing in Allah SWT, His Destiny, and Planning can help individuals to be content and motivate themselves. Taking into account the importance of spirituality as a source of resilience building, the 
application of Islamic elements is the best method in the construction of this model. The results of the analysis found that there are two main concepts that need to be emphasized in Islamic counselling. The first is the concept of knowledge and charity. The concept of knowledge and charity is an important element that needs to be applied to the client. Knowledge plays an important role as a leader in the practice performed. In the context of Islam, knowledge also refers to the confidence and improvement of the heart from one level to a better level. The concept of knowledge and deeds is mentioned a lot in the Qur'an as in surah Al-Qasas (28:80), which means:

"And said those who were given knowledge, "Do not say this - the reward of Allah is better for those who believe and do good deeds, and none can receive it except the patient."

(Surah Al-Qasas ayat 80)

In order to understand how individuals behave and identify their spiritual level, exploration of spiritual resources is an element that counsellors need to do. The application of the concept of knowledge and charity is implemented through the exploration of the purpose of an individual to do something or known as intention. Intention because Allah SWT encourages a person to do something towards good and prevents themselves from doing something that comes harm to themselves. Individuals who do something with intention because Allah SWT has a responsible attitude and does not question destiny and things that happen to them are even satisfied with the provisions given by Allah SWT. In addition, having faith to Allah SWT also explains how individuals submit to Allah and surrender to Him. Surrender to Allah SWT reflects a person who is confident in the power of Allah SWT and makes Allah SWT a place to seek help when disaster strikes. The aspect that is emphasized is also the individual's awareness of the concept of fitrah. The nature to be emphasized in this model is the awareness that human beings do not run away from making mistakes, and they are able to return to their original nature, which is pure and clean (Al-Ghazali, 2000) if they repent and do not repeat the same mistakes. These are the elements that need to be emphasized on the client in the counselling session because its application can encourage contentment, patience and gratitude in the individual, which is a major source of resilience as explained in Surah Ali Imran verse 144, which means:

"And Muhammad is but a Messenger. Previously had passed several messengers. Whether he dies or is killed, you turn back (apostates). And whoever turns back upon his heels, he will not harm Allah in the least; He will repay the grateful."

Surat Ali Imran ayat 144

The second concept is trust and confidence. Trust and having faith in Allah is known as tauhid which is a concept that symbolizes the belief in Islam which is to believe that God is only one, and tauhid is also a union with Allah SWT as explained by the hadith of the Prophet, which means:

"From Abu Hurairah said; that the Prophet PBUH appeared to the companions one day, and Gabriel came to 'Alaihis Salam who then asked: "What is faith?" The Prophet (peace and blessings be upon him) said: "Faith is in Allah, His angels, His books, the meeting with Him, His Messengers, and you believe in the Day of 
Resurrection." (Jibril 'Alaihis salam) said: "What is Islam?" The Prophet PBUH said, "Islam is that you worship Allah and do not associate it with anything, you perform the prayer, you pay the obligatory zakat, and fast during the month of Ramadan". (Gabriel 'Alaihis salam) said: "What is courtesy?" The Prophet (peace and blessings be upon him) said: "You worship Allah as if you had seen Him, and when you do not see Him, He sees you."

(HR Al Bukhari, 1987: 50; Muslim, t.th: 9).

Confidence and belief in the existence of Allah SWT can help individuals form a positive mind, prevent from doing something that harms themselves and does not give up and also no question about the destiny that occurs. This indirectly raises their strength in themselves and, at the same time, can curb stress and extreme anxiety that affects their mental health. The concept of trust and confidence is towards the belief that wants to be instilled in individuals that even if they do not get support from parents, friends, the surrounding community but they still have Allah SWT as a place to complain and ask for help when in trouble. In addition, faith will also help individuals to instil the nature of patience and contentment, which allows them to realize that what happens to them is the wisdom of Allah SWT and every trial and challenge given is a test of Allah SWT even every difficulty there is wisdom to be promised by Allah SWT for those who are able to face it. It is this awareness that needs to be applied in the individual where the application of these elements has the effect of not only building resilience but also helping the individual to become a Muslim who is obedient to Allah SWT.

\section{The Concept of Adler Individual Counseling}

Apart from the spiritual aspect, identifying how individuals form interests, self-esteem and goal setting are key mechanisms to building resilience. Thus, the selection of concepts from Adler's individual counselling coincided with the main goal of building this model. Individual counselling focuses on how individuals perceive themselves through past experiences as an influence on one's life development. According to Ahmad \& Nasir (2013), individual psychology emphasizes the understanding of the whole of the individual self and how aspects or parts of the individual self are interrelated and move towards a single goal. Exploration of social interests, feelings of inferiority, family clusters and past experiences play an important role in helping counsellors understand and analyze clients 'needs and problems.

Lack of love, personality formation, lack of social interest and extremely low self-esteem are among the factors that motivate individuals, especially adolescents, to engage in various activities, including self-harming and useless activities, as a way to find self-strength and selfesteem. Individuals with extremely low self-esteem tend to experience emotional disorders such as depression, sadness, anxiety, depression, and so on, which affect mental health. The ability of individuals to make inferiority a source of inspiration to rise to achieve life goals will enable individuals to compete and function well in society as well as increase self-esteem. This is evidenced by Yasin et al. (2016), where an individual's ability to form self-esteem will contribute to resilience and psychological well-being.

Therefore, a deeper understanding of the individual will help the counsellor to be more sensitive to the developments and issues faced by the client and, at the same time, formulate a variety of appropriate interventions to help the individual build strength and resilience in dealing with stresses, issues and problems. Exploring the individual as a whole will be able to 
help counsellors to analyze, understand and subsequently build the best interventions. Identifying the factors that cause an individual to fail to function fully will help researchers and counsellors to formulate appropriate interventions so that clients can meet any deficiencies and at the same time be able to function fully.

\section{The Role of the Counselor}

Individuals facing mental health problems tend to have feelings of hopelessness and inferiority because they feel that they themselves do not have the opportunity to change and start a better life due to a lack of support systems from society, parents, peers and the environment. This attitude of despair and fear of change becomes an obstacle to the building of resilience in the individual. The high need for a system of support, acceptance, assistance, and guidance indicates that individuals need other individuals as a place to express problems and help them to find the best solutions. Therefore, the role of the counsellor as a listener, mentor and source of support is needed to help individuals in counselling sessions.

The counsellors' expertise in terms of skills, techniques and characteristics is an important element that needs to be emphasized in the intervention process. Thus, in this model, the combined application of Islamic counselling and Adler Individual counselling can be seen in terms of the use of skills and techniques from Individual counselling as well as the application of Islamic elements emphasized in the concept of Islamic counselling. In terms of skills, the use of basic counselling techniques and skills such as questioning, formulating, rephrase and Adler Individual counselling specific techniques such as encouragement, confrontation, and urgency techniques need to be mastered by counsellors to help them perform counselling sessions better. Individual counselling concepts are needed to help counsellors explore and analyze the factors that influence the building of resilience in individuals. Exploration of social interests, past experiences and feelings of inferiority can show how individuals shape their personalities, thoughts, emotional and behavioural changes, as well as help counsellors analyze the need for interventions needed to help them.

In the context of Islamic counselling, the role played by counsellors during counselling sessions is to help create awareness that previous thoughts, behaviours and intentions are wrong and at the same time provide information and guidance to enable adolescents to build better self-awareness and be able to make changes in the future. The application of the concept of trust and confidence as well as knowledge and charity should be made to the client to help them build a good spiritual resource as a form of resilience. In addition, the characteristics that need to be shown by the counsellor as a role model by applying the characteristics of a good Muslim by practising the deeds of 'do good things and avoid bad things, patience, sincerity, faith and even make the praiseworthy morals of Rasulullah saw as a reference. A balance between these skills and characteristics needs to be achieved to enable counsellors to be congruent. According to Othman (2019), the personality shown by the counsellor in the counselling session is a role model that can be used as a reference to build the client's personality and attitude and even affect how the client shapes their behaviour, emotions and thought. 




\section{Conclusion}

Lack of resources mainly involving the best concepts to be applied in intervention methods especially involving Islamic counselling, is a limitation faced by researchers. Therefore, looking at this importance, the study involving content analysis on the Quran, Hadith and literature review has been carried out in an orderly manner and has successfully identified some key concepts from both approaches to be applied in the construction of intervention models. The concept of knowledge and deeds that emphasize the elements of nature, trust and sincerity is accompanied by the concept of belief in Allah and His power through the application of the practice of faith, Islam and compassion in oneself is a basic concept that was successfully identified in this study. Both of these concepts are basic things needed by individuals, especially Muslim individuals, to build spiritual strength because sufficient knowledge and accompanied by practice and belief is able to help individuals build good resilience in themselves. From the point of view of Adler's Individual counselling, the concepts of social interests, past experiences, family clusters, feelings of inferiority and lifestyle are seen as concepts that need to be applied to help address mental health issues. These concepts are seen to play an important role, especially in helping counsellors explore, understand and obtain in-depth information on the client especially involving its influence on the development and formation of individual personality.

In addition to the conceptual findings from both approaches, this study also succeeded in identifying the importance of the role played by counsellors in counselling sessions. The role of counsellors in terms of characteristics such as unconditional acceptance, empathy, patience, honesty, confidence, non-judgmental attitude by practising admirable qualities along with counselling skills and techniques are elements that also affect the success of a counselling session conducted. The ability of counsellors to conduct counselling sessions well, apply the concepts found in the intervention model through the techniques shown is seen to be able to help individuals increase self-awareness and the ability to be better literate and even affect the success of the sessions.

Therefore, through this finding, the combination of Islamic counselling concept, Adler Individual counselling and the role of a counsellor is a key element applied in the construction of the intervention model because these elements complement each other and are able to 
increase individual resilience as one way to address mental health issues. This study also successfully explores the importance of concepts from both approaches that are truly suitable to be applied as resilience-building resources. In addition, the construction of the intervention model also has a good balance involving individual development and spiritual aspects. It also has a clear framework and is easy to apply by counsellors in the session and a guide to constructing more structured construction modules in the future. More comprehensive studies can be done, explored, and developed by researchers in the future to construct models, modules, intervention methods, etc. This article is one of the mediums to introduce Islamic counselling to the community and counsellors. It is hoped that this article can be one of the best platforms for researchers to do more research in the future, especially as a guide for the construction of modules, interventions, models that can be explored to be practised in the world of counselling.

\section{Acknowledge}

Funded by Ministry of Higher Education for FRGS project with FRGS/1/2018/SS05/UTM/02/4 code

\section{Reference}

Abd Majid, M., Azman, N. Z., \& Yani, M. N. I. (2019). Teenagers' Involvement Factor In Sexual Misconduct: A Study On Teenagers' Premarital Pregnancy In Selangor State Moral Rehabilitation Centre Al-Irsyad: Journal Of Islamic And Contemporary Issues. Vol. 4, No. 2, Dec 201. E-Issn 2550-1992

Al-Ghazali \& Ahmad, A. H. M. (2000). Ihya' 'Ulum al-Din. Kaherah: Dar al-Taqwa li al-Turath. Al-Quran. (2012). Al-Wasim, Quran Translation. Publications of Cipta Bagus Segara: Indonesia Ahmad, N. S., \& Nasir, R. (2013). Aplikasi Praktik Teori Kaunseling dan Psikoterapi. Penerbitan Universiti Kebangsaan Malaysia. Bangi. Malaysia

Amila, A. H., Sham. M. F., Mohamed, H. A. (2017). Pendekatan Motivasi dalam Menangani Tingkah Laku Remaja Berisiko. Fikiran Masyarakat, Vol. 5(1). ISSN No. 2338-512X.

Awang, A. (2016). Kaunseling di abad 21-suatu anjakan paradigma: dari konvensional kepada islamik. In Asean Psychology and Counselling Conference.

Badri, M. (2000). Contemplation: An Islamic Psychospiritual Study. London: Washington. ISBN 978-1-56564-566-0.

Diniaty, A. (2013). Urgensi Teori Konseling dan Perspektifnya Dalam Islam Menjawab Tuntutan Konseling Religius Di Masa Depan. Al-Ta'Lim, 20(1): 312. https://doi.org/10.15548/jt.v20i1.27

Tunggak, B., Ngadi, S., \& Abu Naim, H. A. (2015). Delinkuen pelajar dan cadangan penyelesaiannya menerusi model pembangunan sahsiah remaja/pelajar Muslim bersepadu. Jurnal Hadhari, 7 (2): 11-30.

Jessie, W., \& James, T. N. (2017). Coping Strategies and The Development Of Psychological Resilience. Journal of Outdoor and Environmental Education, 20(1): 47-54.

Khalid, N. F. (2017). Kesan Kaunseling Kelompok Perkembangan dan Rawatan Terhadap Konsep Kendiri, Resilien dan Daya Tindak Pelajar SMKA. Universiti Pendidikan Sultan Idris. Malaysia.

Ibrahim, I., \& Muhammad, H. (2016). Level of Resilience amongst Public University Students in Malaysia and Overseas. Jurnal Personalia Pelajar, 19: 92 -107. 
Masroom, M. N., Muhamad, S. N., \& Abd Rahman, S. I. (2015). Kebimbangan dari perspektif psikologi Islam dan cara mengatasinya berdasarkan Surah Al-Ma'arij. Sains Humanika, 5 (1): 61-67. ISSN 2289-6996.

Mamat, S. (2016). Tahap Kecerdasan Emosi Dalam Kalangan Remaja Di Kolej Universiti Islam Melaka. Jurnal Sains Sosial, 1: 115-136.

Jailani, M. R., \& Osman, A. B. (2015). Integrasi terapi psikospiritual Islam dalam modul rawatan dan rehabilitasi berasaskan Tc Therapeutic Community. Proceeding Prevent 2015 (International Drug Prevention And Rehabilitation Conference). Acreda, Universiti Sains Islam Malaysia. Retrieved January 12, 2018, from http://ddms.usim.edu.my/jspui/handle/123456789/14898?mode=full

Muhammad, A. A. W., Abdul, G., \& Yusof, H. (2017). Perbincangan Awal Kajian Lepas Berkaitan Kesejahteraan Hidup. Proceeding of International Conference of Empowering Islamic Civilization (c) Research Institute for Islamic Product and Malay Civilization (INSPIRE) Universiti Sultan Zainal Abidin (UniSZA) ISBN 978-967-0899-70-1 (2017), http: //www.inspire.unisza.edu.my

Mohamad, Z., \& Rathnakrishnan, B. (2014). Hubungan Daya Ketahanan dan Sokongan Sosial Terhadap Kesunyiaan Pelajar Dalam Institusi Pengajian Tinggi. National Seminar on Family Integrity 2014: ISBN: 978-967-0582-32-0.

Nen, S., \& Ibrahim, K. A. (2018). Students' Perceptions Toward Counselling Services In The University Of Kebangsaan Malaysia. Journal of Social Sciences and Humanities,15 (4): 93-103.

Othman, N. (2019). Islamic Counselling: An Integrated Approach in Promoting Psychological Well-Being. International Journal of Academic Research in Business and Social Sciences, 9(3). E-ISSN: 2222 -6990 (C) 2019 HRMARS.

Sanu, M. E., \& Rathakrishnan, B. (2019). Coping Strategies as a Mediator in Relationship of Emotional Intelligence and Psychological Well-Being among Poor Rural Students in Sabah. Journal of Advanced Research In Social And Behavioral Sciences, 14 (1):9-15.

Yaacob, N. R. N. (2012). Cognitive Therapy Approach from Islamic Psycho-Spiritual Conception. Procedia-Social and Behavioral Sciences 97 (2013) 182-187. Elsevier.

Yasin, N., Manap, J., \& Kassim, A. C. (2018). The Self-Esteem Influence on Psychological WellBeing Among Mualaf. e-BANGI, 13(3): 173-182. 